\title{
ЗМІНИ БІОХІМІЧНИХ ПОКАЗНИКІВ У КРОВІ ВИСОКО- ТА НИЗЬКОЕМОЦЙНИХ ЩУРІВ ПРИ ЕТАНОЛОВОМУ ГЕПАТОЗІ
}

Вступ. Визначення механізмів ушкоджувального впливу етанолу на печінку у тварин з різною реактивністю може сприяти розробці нових методів лікування та профрілактики алкогольного ураження органів і систем.

Мета дослідження - виявити механізми ушкоджувального впливу при етаноловому гепатозі на організм високо- (BE) та низькоемоційних (HE) щурів-самців.

Методи дослідження. Досліди виконано на 72 ВЕ і НЕ безпородних щурах-самцях віком 5,5-6 місяців. Тварин було поділено на 3 групи: контроль 1 (К1), контроль 2 (К2) та етаноловий гепатоз (ЕГ). Емоційний стан щурів визначали за методикою "відкрите поле". Щури групи К2 протягом 67 днів замість води отримували 5 \% розчин глюкози, тварини групи ЕГ - 10 \% розчин етилового спирту, розведеного 5 \% розчином глюкози. У сироватці крові визначали рівень аланін- та аспартатамінотрансферази, лужної фросфратази, загального білка, глюкози, показників окисної модифрікації білків, дієнових і трієнових кон'югатів, шифрфових основ, активність супероксиддисмутази, каталази, вміст церулоплазміну і пероксидазну активність крові. Забирали печінку для морфрологічного дослідження.

Результати й обговорення. У НЕ щурів групи К1 відмічено більші активність процесів пероксидного окиснення ліпідів, концентрацію глюкози, менші рівень аланінамінотрансферази, вміст білка. При ЕГ продукти пероксидного окиснення ліпідів зменшилися одночасно з підвищенням активності антиоксидантів, але зріс вміст продуктів окисної модифрікації білків, знизився вміст загального білка, більше у ВЕ тварин; збільшилась глюкоза. У ВЕ щурів знизився рівень аланінамінотрансорерази, у НЕ тварин він підвищився. Печінка була більш уражена у ВЕ тварин.

Висновок. Моделювання етанолового гепатозу в щурів з різною емоційністю спричинює ураження гепатоцитів унаслідок зростання окисної модифрікації білків, що більш виражено у ВЕ тварин.

КЛЮЧОВІ СЛОВА: етаноловий гепатоз; високо- і низькоемоційні щури-самці; кров; печінка.

ВСТУП. Алкогольні ураження печінки за поширеністю і соціальним значенням займають друге місце після гострих та хронічних захворювань печінки вірусної етіології. При вживанні близько 90 \% алкоголю піддається метаболізму в печінці з утворенням токсичної для неї речовини - ацетальдегіду. Продукти розпаду алкоголю негативно впливають на клітини печінки призводять до їх гіпоксії, а потім до некрозу [1]. Вивчення механізмів впливу етанолу і його метаболітів на біомембрани при алкогольному ураженні печінки в щурів дозволяє зрозуміти фундаментальні основи виникнення та розвитку патологічного процесу. Однією з основних гістологічних особливостей розвитку алкогольного гепатиту є жирова дистрофрія, при цьому її розвиток пов'язаний насамперед із порушенням метаболізму жирних кислот внаслідок перетворення етанолу в ацетальдегід та ацетат [2].

сО. А. Костюк, О. В. Денефіль, Т. К. Головата, 2018.
Зловживання алкоголем сприяє розвитку захворювань і прямо або побічно є однією 3 найважливіших причин смертності населення. Етанол уражає всі органи і тканини організму, ускладнює перебіг багатьох захворювань. Отримані за останні роки результати наукових досліджень щодо впливу алкоголю на організм людини та експериментальних тварин поповнюють і поглиблюють сучасні уявлення про особливості дії етанолу в організмі [3]. Відомо, що тяжкість етанолових уражень залежить від дози, тривалості вживання та індивідуальної реактивності організму. Останнє вивчено найменше.

Мета дослідження - виявити механізми ушкоджувального впливу при етаноловому гепатозі на організм високо- (BE) та низькоемоційних (HE) щурів-самців.

МЕТОДИ ДОСЛІДЖЕННЯ. ДосліДи виконано на 72 BE і НЕ безпородних щурах-самцях віком 
5,5-6 місяців. Тварин було поділено на 3 групи: контроль 1 (К1), контроль 2 (К2) та етаноловий гепатоз (ЕГ).

Для визначення емоційного стану щурів тестували за методикою "відкрите поле" [4-6]. Тварин групи К1 утримували на стандартному харчовому раціоні віварію протягом усього періоду моделювання гепатозу та з вільним доступом до води для пиття, щурів групи К2 - на стандартному харчовому раціоні віварію протягом усього періоду моделювання гепатозу, але для пиття замість води вони отримували $5 \%$ розчин глюкози. Етаноловий гепатоз моделювали шляхом давання $10 \%$ розчину етилового спирту як єдиного джерела пиття, розведеного $5 \%$ розчином глюкози, тривалістю 60 днів. Попередньо проводили адаптацію тварин до етилового спирту, даючи їм протягом 7 днів як єдине джерело пиття $5 \%$ розчин етанолу, розведений $5 \%$ розчином глюкози, в поїлках.

Усі експерименти проводили в першій половині дня в спеціально відведеному приміщенні при температурі $18-22^{\circ} \mathrm{C}$, відносній вологості 40-60 \% і освітленості 250 лк. Досліди виконано з дотриманням норм Європейської конвенції про захист хребетних тварин, що використовуються для дослідних та інших наукових цілей (Страсбург, 1986), ухвали Першого національного конгресу з біоетики (Київ, 2001) і наказу МОЗ України від 23.09.2009 р. № 690.

Евтаназію щурів проводили шляхом тотального кровопускання із серця після попереднього тіопентал-натрієвого наркозу (60 мг $\cdot \mathrm{r}^{-1}$ маси тіла тварини внутрішньочеревно). У сироватці крові визначали рівень аланінамінотранссерази (АлАТ), аспартатамінотранссрерази (АсАТ), лужної фоссратази (ЛФ), загального білка, глюкози, показників окисної модисрікації білків (ОМБ ${ }_{370} \mathrm{Ta}$ $\mathrm{OMБ}_{430}$ ), дієнових (ДК) і трієнових кон'югатів (ТК), шифрфових основ (ШО), активність супероксид- дисмутази (СОД), каталази, вміст церулоплазміну (ЦП) і пероксидазну активність крові (ПАК) [2, 3, 7-10]. Забирали печінку для морфологічного дослідження.

Статистичну обробку цисрових даних виконано за допомогою програмного забезпечення Excel ("Microsoft", США) i STATISTICA 6.0 ("Statsoft", США). Достовірність різниці значень між незалежними кількісними величинами визначали при нормальному розподілі за критерієм Стьюдента, в інших випадках - за допомогою непараметричних методів.

РЕЗУЛЬТАТИ Й ОБГОВОРЕННЯ. ЯК СВіДчаТЬ результати аналізу змін показників пероксидного окиснення ліпідів (табл. 1), вміст ДК при ЕГ у ВЕ тварин знизився на 23,3 \% $(p<0,001)$ порівняно 3 групою К1 та на 18,3 \% ( $<<0,001)$ порівняно 3 групою К2. У НЕ щурів він також зменшився в групі ЕГ: порівняно з К1 - на $51 \%$ $(p<0,001)$, порівняно з К2 - на $19 \%(p<0,001)$. Порівнюючи у ВЕ тварин показники ДК, встановили, що в групі К2 вони були вищими, ніж у групі К1, на $31 \%(p<0,001)$, а у НЕ щурів - навпаки: в групі К1 на 27 \% (p<0,001) більшими, ніж у групі К2. У НЕ тварин групи К1 значення ДК були достовірно вищими, ніж у ВЕ щурів, на $33 \%$ $(p<0,001)$, а в НЕ тварин групи К2 - на $25 \%$ $(p<0,001)$ нижчими, ніж у ВЕ щурів.

Показники ТК при ЕГ у ВЕ тварин були на $24 \%(p<0,001)$ більшими порівняно з групою К1, але на $10 \%(p<0,001)$ меншими, ніж у групі К2. У НЕ щурів групи К1 значення ТК були на $7 \%$ $(p<0,01)$, а групи К2 - на $24 \%(p<0,001)$ вищими, ніж при ЕГ. У тварин достовірно більшими були показники ТК: у ВЕ групи К2 - на 36 \% $(p<0,001)$ порівняно з групою К1, у НЕ групи К1 - на $24 \%$ $(p<0,001)$ порівняно 3 групою К2. У ВЕ щурів групи К1 значення ТК були нижчими на $35 \%$ $(p<0,001)$, групи К2 - вищими на $25 \%(p<0,001)$ порівняно з НЕ тваринами.

Таблиця 1 - Зміни показників пероксидного окиснення ліпідів у сироватці крові, викликані дією етанолу, у високо- і низькоемоційних тварин ( $\mathrm{M} \pm \mathrm{m}, \mathrm{n}=12)$

\begin{tabular}{|c|c|c|c|}
\hline \multirow{2}{*}{ Група } & \multicolumn{3}{|c|}{ Показник } \\
\hline & ДК, ум. оД. & ТК, ум. од. $\cdot$ мл $^{-1}$ & ШО, ум. од. мл $^{-1}$ \\
\hline \multicolumn{4}{|c|}{ ВЕ тварини } \\
\hline Контроль 1 & $2,867 \pm 0,005$ & $2,665 \pm 0,005$ & $2,514 \pm 0,021$ \\
\hline Контроль 2 & $3,750 \pm 0,009^{*}$ & $3,636 \pm 0,014^{*}$ & $2,076 \pm 0,004^{*}$ \\
\hline Етаноловий гепатоз & $2,325 \pm 0,064^{*, * *}$ & $3,308 \pm 0,027^{*, * *}$ & $2,399 \pm 0,052^{*, \star *}$ \\
\hline \multicolumn{4}{|c|}{ НЕ тварини } \\
\hline Контроль 1 & $3,801 \pm 0,022^{\#}$ & $3,6 \pm 0,022^{\#}$ & $2,107 \pm 0,01^{\#}$ \\
\hline Контроль 2 & $2,995 \pm 0,013^{*}, \#$ & $2,904 \pm 0,015^{*, \#}$ & $2,434 \pm 0,024^{*}, \#$ \\
\hline Етаноловий гепатоз & $2,517 \pm 0,076^{*, * *}$ & $3,35 \pm 0,034^{*, * *}$ & $2,572 \pm 0,077^{\star}$ \\
\hline
\end{tabular}

Примітки. Тут і в таблицях 2-5:

1. * - показники достовірні порівняно з контролем 1.

2. ** - показники достовірні порівняно з контролем 2.

3. \# - показники достовірні порівняно з ВЕ тваринами. 
При ЕГ у ВЕ тварин показники ШО були на $5 \%(p<0,001)$ нижчими, ніж у групі К1, та на $16 \%$ $(p<0,001)$ вищими порівняно 3 групою K2, а у $\mathrm{HE}$ - більшими на $22 \%(p<0,001)$ порівняно 3 групою К1. Достовірно вищими були значення у BE щурів групи К1 порівняно з $\mathrm{HE}$ - на $19 \%$ $(p<0,001)$, у НЕ тварин групи К2 порівняно з ВЕ на $17 \%(p<0,001)$.

При ЕГ у ВЕ тварин виявлено більшу кількість ОМБ ${ }_{370}$, про що свідчили достовірно вищі на $129 \%(p<0,001)$ значення порівняно з групою К1 та на $448 \%(p<0,001)$ більші порівняно 3 групою К2 (табл. 2). При ЕГ у НЕ щурів показники також були суттєво вищими, ніж у контрольних групах: на $267 \%(p<0,001)$ порівняно з К1 та на $56 \%(p<0,001)$ порівняно з К2. Значення ОМБ ${ }_{370}$ при ЕГ У ВЕ тварин були на $50 \%$ $(p<0,001)$ більшими, ніж у НЕ. Порівнюючи дані показники у ВЕ тварин груп К1 і К2, помітили, що в групі К1 вони були вищими на $139 \%$ $(p<0,001)$, а у НЕ щурів - навпаки: в групі К2 на $135 \%(p<0,001)$ більшими, ніж у групі К1. У ВЕ щурів групи К1 значення ОМБ ${ }_{370}$ були вищими, ніж у НЕ, на $141 \%$, а групи К2 - нижчими на $133 \%$ порівняно з ВЕ.

При ЕГ у ВЕ тварин достовірно збільшувалися показники ОМБ ${ }_{430}$ - на 59 \% $(\mathrm{p}<0,001)$ порівняно з НЕ: у ВЕ щурів групи К1 - на $64 \%$ $(p<0,001)$ порівняно $3 \mathrm{HE}$, у НЕ тварин групи К2 - на $65 \%(p<0,001)$ порівняно з ВЕ. А також при ЕГ у ВЕ щурів значення ОМБ ${ }_{430}$ були на $68 \%$ $(p<0,001)$ вищими, ніж у групі К2. У НЕ тварин дані показники при ЕГ були нижчими, порівняно 3 групою К2, на 57 \% ( $(p<0,001)$. У ВЕ щурів групи К1 значення ОМБ ${ }_{430}$ були на $75 \%(p<0,001)$ більшими, ніж у групі К2, а у НЕ тварин - навпаки: у групі К2 вищими на $52 \%(p<0,001)$, ніж у групі К1.

При ЕГ значення СОД у ВЕ тварин були вищими на $87 \%(p<0,05)$ порівняно з групою К1 та на $13 \%(p<0,01)$ порівняно 3 групою К2 (табл. 3). Достовірно показники СОД у ВЕ щурів збільшувалися у групі К2 на 66 \% $(p<0,001)$ порівняно з групою К1. У НЕ тварин, навпаки, вони підвищувалися: в групі К1 - на 60 \% $(p<0,001)$ порівняно з групою К2, при ЕГ - на $57 \%(p<0,001)$ порівняно 3 групою К2. У ВЕ щурів групи К1 активність фрерменту була меншою на $70 \%$ $(p<0,001)$ порівняно $3 \mathrm{HE}$, а групи К2 - на $56 \%$ $(p<0,001)$ більшою порівняно з НЕ.

Рівень каталази в сироватці крові при ЕГ був достовірно вищим: у ВЕ тварин - на $30 \%$ $(p<0,001)$ порівняно з HE, на $319 \%(p<0,001)$ порівняно з групою К1 та на 84 \% $(p<0,001)$ порівняно $з$ групою К2. Показники каталази достовірно збільшувалися у ВЕ щурів групи К2 - на 128 \% $(p<0,001)$ порівняно 3 групою К1. У НЕ тварин групи К1 значення каталази були вищими, ніж у групі К2, на $124 \%$ (p<0,001), при ЕГ - на $188 \%(p<0,001)$ порівняно 3 групою К2, у НЕ щурів групи К1 - на $151 \%(p<0,001)$ порівняно з ВЕ, у ВЕ тварин групи К2 - на $103 \%(\mathrm{p}<0,001)$ порівняно $3 \mathrm{HE}$, у НЕ щурів при ЕГ - на $28 \%$ $(p<0,001)$ порівняно 3 групою К1.

Таблиця 2 - Зміни показників окисної модифрікації білків у сироватці крові, викликані дією етанолу, у високо- і низькоемоційних тварин ( $\mathrm{M} \pm \mathrm{m}, \mathrm{n}=12)$

\begin{tabular}{|c|c|c|}
\hline \multirow{2}{*}{ Група } & \multicolumn{2}{|c|}{ ППоказник } \\
\hline & $\mathrm{OMБ}_{370}$, ммоль/г білка & $\mathrm{OMБ}_{430}$, ммоль/г білка \\
\hline \multicolumn{3}{|c|}{ ВЕ тварини } \\
\hline Контроль 1 & $0,282 \pm 0,005$ & $0,365 \pm 0,007$ \\
\hline Контроль 2 & $0,118 \pm 0,002^{*}$ & $0,208 \pm 0,006^{\star}$ \\
\hline Етаноловий гепатоз & $0,647 \pm 0,009^{*, * *}$ & $0,349 \pm 0,007^{\star *}$ \\
\hline \multicolumn{3}{|c|}{ НЕ тварини } \\
\hline Контроль 1 & $0,117 \pm 0,001$ & $0,222 \pm 0,002$ \\
\hline Контроль 2 & $0,275 \pm 0,004^{*}, \#$ & $0,344 \pm 0,008^{*, \#}$ \\
\hline Етаноловий гепатоз & $0,430 \pm 0,007^{*, * *, \#}$ & $0,219 \pm 0,003^{* *, \#}$ \\
\hline
\end{tabular}

Таблиця 3 - Зміни показників антиоксидантної системи в сироватці крові,

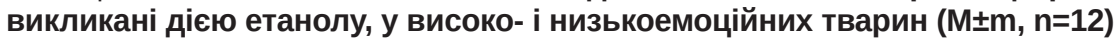

\begin{tabular}{|c|c|c|c|c|}
\hline \multirow{2}{*}{ Група } & \multicolumn{4}{|c|}{ Показник } \\
\hline & СОД, пит. од./мл & каталаза, мкат/л & ПАК, мкмоль/(хв·л) & ЦП, мг/л \\
\hline \multicolumn{5}{|c|}{ ВЕ тварини } \\
\hline Контроль 1 & $0,207 \pm 0,001$ & $0,107 \pm 0,001$ & $0,534 \pm 0,011$ & $3,767 \pm 0,040$ \\
\hline Контроль 2 & $0,344 \pm 0,007^{*}$ & $0,244 \pm 0,007^{*}$ & $0,775 \pm 0,030^{*}$ & $2,596 \pm 0,031^{*}$ \\
\hline Етаноловий гепатоз & $0,387 \pm 0,012^{*, * *}$ & $0,449 \pm 0,008^{*, * *}$ & $1,116 \pm 0,044^{*, * *}$ & $4,424 \pm 0,069^{*, * *}$ \\
\hline \multicolumn{5}{|c|}{ НЕ тварини } \\
\hline Контроль 1 & $0,352 \pm 0,007^{\#}$ & $0,269 \pm 0,005^{\#}$ & $0,772 \pm 0,026^{\#}$ & $2,208 \pm 0,020^{\#}$ \\
\hline Контроль 2 & $0,220 \pm 0,002^{*}, \#$ & $0,120 \pm 0,003^{*, \#}$ & $0,526 \pm 0,003^{*, \#}$ & $3,616 \pm 0,053^{*, \#}$ \\
\hline Етаноловий гепатоз & $0,345 \pm 0,011^{* *}$ & $0,345 \pm 0,008^{*, * *, \#}$ & $1,012 \pm 0,055^{*, *}$ & $3,654 \pm 0,054^{*}, \#$ \\
\hline
\end{tabular}


Показники ПАК і ЦП достовірно збільшувалися при ЕГ. У ВЕ щурів пероксидазна активність крові при ЕГ була вищою на 109 \% $(p<0,001)$ порівняно з групою К1 та на $44 \%$ (p<0,001) більшою, ніж у групі К2, у НЕ тварин - вищою на 31 \% $(p<0,001)$ порівняно 3 групою К1 і на $92 \%$ $(p<0,001)$ більшою, ніж у групі К2. У НЕ щурів вона була вищою в групі К1 на $45 \%(p<0,001)$ порівняно з ВЕ, а у ВЕ тварин групи К2 - більшою, ніж у НЕ, на $47 \%(p<0,001)$. У ВЕ щурів ПАК у групі К2 була достовірно вищою на $45 \%$ $(p<0,001)$ порівняно з групою K1, а у НЕ тварин навпаки: у групі К1 на 47 \% $(p<0,001)$ більшою, ніж у групі К2.

Вміст ЦП достовірно збільшувався при ЕГ у ВЕ тварин на $21 \%(p<0,001)$ порівняно $3 \mathrm{HE}$, у ВЕ щурів групи $\mathrm{K} 1$ - на $45 \%(p<0,001)$ порівняно 3 групою К2, у НЕ тварин групи К2 - на $64 \%$ $(\mathrm{p}<0,001)$ порівняно з групою К1, у ВЕ щурів при ЕГ - на $17 \%(p<0,001)$ порівняно з групою К1 i на $70 \%(p<0,001)$ порівняно з групою К2. Також помітно вищим залишався вміст ЦП у НЕ тварин при ЕГ - на $65 \%(p<0,001)$ порівняно з групою K1, в групі К2 - на $39 \%(p<0,001)$ порівняно 3 BE, а в групі К1 - навпаки: у ВЕ щурів його показники були більшими на $71 \%(p<0,001)$.

Рівень АлАТ при ЕГ у ВЕ тварин був нижчим на $69 \%(p<0,001)$ порівняно з групою К1 та на $72 \%(p<0,001)$ порівняно з групою К2 (табл. 4). У НЕ щурів при ЕГ виявлено значно вищі показники АлАТ: на $73 \%(\mathrm{p}<0,001)$ порівняно $з$ групою K1 і на $45 \%(p<0,001)$ порівняно 3 групою К2. При ЕГ у НЕ тварин значення АлАТ були біль- шими, ніж у ВЕ щурів, на $138 \%(p<0,001)$. Рівень АлАТ достовірно був вищим у НЕ тварин групи К2 - на $19 \%(p<0,001)$ порівняно з групою К1, у ВЕ щурів групи $\mathrm{K} 1$ - на $23 \%(\mathrm{p}<0,001)$ порівняно $3 \mathrm{HE}$.

Рівень АсАТ при ЕГ був нижчим у ВЕ тварин на $34,8 \%(p<0,001)$ порівняно 3 групою K2, у групі К2 порівняно з групою К1 - вищим на 27,3 \% $(p<0,01)$. Помітно більшим залишався рівень AсAT у ВЕ щурів групи К2 - на $19 \%(p<0,05)$ порівняно $3 \mathrm{HE}$ тваринами групи К2.

Рівень ЛФ тільки при ЕГ у ВЕ щурів був вищим на $18,5 \%(p<0,001)$ порівняно 3 групою К2.

При аналізі змін рівня глюкози помітним було значне збільшення ії значень у ВЕ тварин при ЕГ - у 8,1 раза $(p<0,001)$ порівняно з групою К1 та в 7,2 раза $(\mathrm{p}<0,001)$ порівняно 3 групою К2 (табл. 5). Показники глюкози достовірно підвищувалися у НЕ щурів при ЕГ - у 3 рази $(p<0,001)$ порівняно $з$ групою К1 і на 18 \% $(p<0,001)$ порівняно 3 групою К2. Порівнюючи значення у НЕ тварин груп К1 та К2, ми помітили, що у групі К2 результати більші, ніж у групі К1, у 2,6 раза $(p<0,001)$. У НЕ щурів групи К1 показники глюкози були достовірно вищими, ніж у ВЕ тварин, у 2,6 раза $(p<0,001)$, а в HE щурів групи К2 - у 6 разів $(p<0,001)$ нижчими, ніж у ВЕ.

При аналізі вмісту загального білка відмічено зниження його показників як у ВЕ, так і в НЕ тварин при ЕГ, яке можна пояснити пригніченням білоксинтетичної фрункції. Так, у ВЕ тварин при ЕГ рівень білка був меншим, ніж у групі К1, на

Таблиця 4 - Зміни показників амінотрансфераз та лужної фоссратази в сироватці крові,

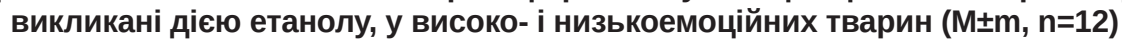

\begin{tabular}{|l|c|c|c|}
\hline \multirow{2}{*}{ Група } & \multicolumn{3}{|c|}{ Показник } \\
\cline { 2 - 4 } & АлАТ, ум. од. $\cdot$ м $^{-1}$ & АсАТ, ум. оД. мл $^{-1}$ & ЛФ, ум. од. $\cdot$ мл $^{-1}$ \\
\hline \multicolumn{3}{|c|}{ ВЕ тварини } \\
\hline Контроль 1 & $83,050 \pm 2,463$ & $122,775 \pm 5,475$ & $232,183 \pm 6,846$ \\
\hline Контроль 2 & $84,658 \pm 2,383$ & $156,350 \pm 4,602^{*}$ & $217,125 \pm 2,066$ \\
\hline Етаноловий гепато3 & $49,183 \pm 1,794^{*, * *}$ & $115,917 \pm 4,722^{* *}$ & $257,467 \pm 5,859^{* *}$ \\
\hline \multicolumn{4}{|c|}{ НЕ тварини } \\
\hline Контроль 1 & $67,500 \pm 1,547^{\#}$ & $137,767 \pm 7,274$ & $215,383 \pm 9,022$ \\
\hline Контроль 2 & $80,458 \pm 0,613^{*}$ & $131,417 \pm 7,811^{\#}$ & $212,667 \pm 14,054$ \\
\hline Етаноловий гепато3 & $117,067 \pm 4,642^{* * * *, *}$ & $127,308 \pm 7,014$ & $255,183 \pm 2,919$ \\
\hline
\end{tabular}

Таблиця 5 - Зміни показників глюкози та загального білка в сироватці крові, викликані дією етанолу, у високо- і низькоемоційних тварин ( $\mathrm{M} \pm \mathrm{m}, \mathrm{n}=12)$

\begin{tabular}{|l|c|c|}
\hline \multirow{2}{*}{ Група } & \multicolumn{2}{c|}{ Показник } \\
\cline { 2 - 3 } & \multicolumn{2}{|c|}{ глюкоза, ммоль/л } \\
\hline \multicolumn{3}{|c|}{ ВЕ тварини } \\
\hline Контроль 1 & $5,667 \pm 0,142$ & $75,025 \pm 4,767$ \\
\hline Контроль 2 & $6,358 \pm 0,261$ & $50,075 \pm 1,654^{*}$ \\
\hline Етаноловий гепато3 & $45,879 \pm 0,763^{*, * *}$ & $41,425 \pm 0,891^{*, * *}$ \\
\hline \multicolumn{3}{|c|}{ HЕ тварини } \\
\hline Контроль 1 & $14,689 \pm 0,57^{\#}$ & $61,383 \pm 1,351^{\#}$ \\
\hline Контроль 2 & $37,922 \pm 1,153^{*}, *$ & $54,242 \pm 1,059^{*}$ \\
\hline Етаноловий гепато3 & $44,693 \pm 0,813^{*, * *}$ & $31,2 \pm 1,418^{*, * * *}$ \\
\hline \hline
\end{tabular}


$81,1 \%$ ( $<<0,001)$ і на 20,8 \% ( $p<0,001)$ порівняно 3 групою К2. Достовірно більшими були показники групи К1 порівняно з групою К2: у ВЕ - на $50 \%(p<0,001)$, а в HE - на $13 \%(p<0,001)$. У HE тварин значення були вищими: в групі К1 - на $97 \%(p<0,001)$, у групі К2 - на $74 \%(p<0,001)$ порівняно з групою ЕГ. У ВЕ щурів групи ЕГ показники були вищими на $33 \%(p<0,001)$ порівняно з НЕ, у ВЕ тварин групи К1 - на $22 \%$ $(p<0,001)$ більшими, ніж у НЕ.

Аналіз гістоструктури печінки ВЕ тварин показав, що головними гістологічними проявами ії̈ ураження були втрата класичної балково-радіальної структури часточок та гіаліново-краплинна дистрофрія гепатоцитів, яка мала дисузний характер, поширюючись на всю часточку, або ж займала тільки окремі її фрункціональні зони. У таких клітинах виявляли конденсацію

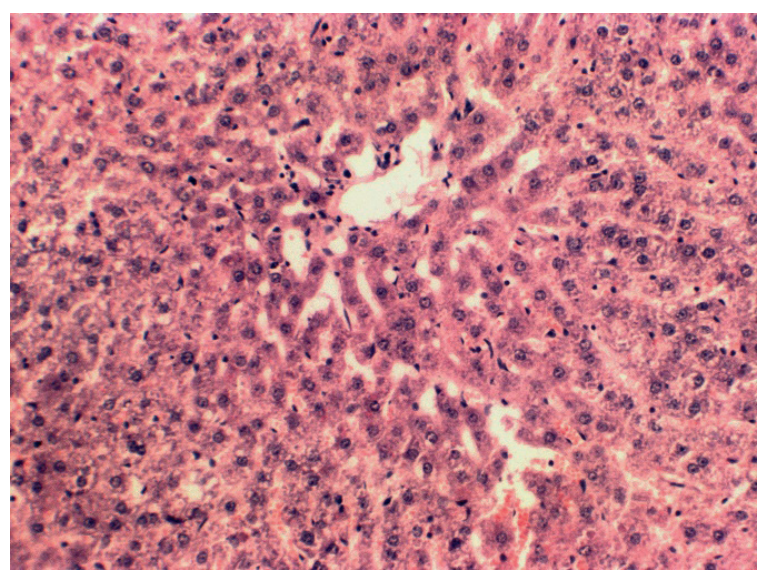

Рис. 1. Дискомплексація печінкових балок переважно центральних та периферичних зон їх гіаліново-краплинною і балонною дистрофією, деякі клітини розпадаються на фррагменти. Ядра поліморфні, з крайовим розташуванням хроматину. Гістологічний зріз печінки високоемоційного щура. Забарвлення гематоксиліном і еозином. ×100.

ВИСНОВКИ. 1. У НЕ тварин групи К1 відмічено більші активність процесів пероксидного окиснення ліпідів, концентрацію глюкози, менші рівень АлАТ, вміст білка.

2. При ЕГ продукти пероксидного окиснення ліпідів зменшуються одночасно з підвищенням активності антиоксидантів, але зростає вміст продуктів ОМБ, знижується вміст загального білка, більше у ВЕ тварин; зростає глюкоза. У

\section{СПИСОК ЛІТЕРАТУРИ}

1. Кононенко А. Г. Вивчення гепатозахисної дії водного екстракту листків кукурудзи на моделі субхронічного алкогольного ураження печінки / А. Г. Кононенко // Ukrainian biopharmaceutical journal. - 2014. 35, № 6 . - C. 43-45. хроматину та набухання ядер. Часто, переважно в центрах часточок, спостерігали розпад клітин на фррагменти. Частина клітин, зберігаючи цілісність мембрани, мала оптично порожню цитоплазму (рис. 1).

У НЕ тварин мікроскопічне дослідження печінки виявило комплекс змін, які відрізнялися від описаних у попередній групі значно легшими проявами. Балково-радіальна структура часточок та диференціація їх на зони в цілому зберігалися. Проте нерідко виявляли ділянки дискомплексації, які зустрічалися як у центрах, так і в периферичних зонах часточок. У більшості випадків превалювали слабо чи помірно виражені дистросрічні зміни гепатоцитів поряд із незміненими клітинами. Деструктивні зміни обмежувалися поодинокими клітинами або їх невеликими групами (рис. 2).

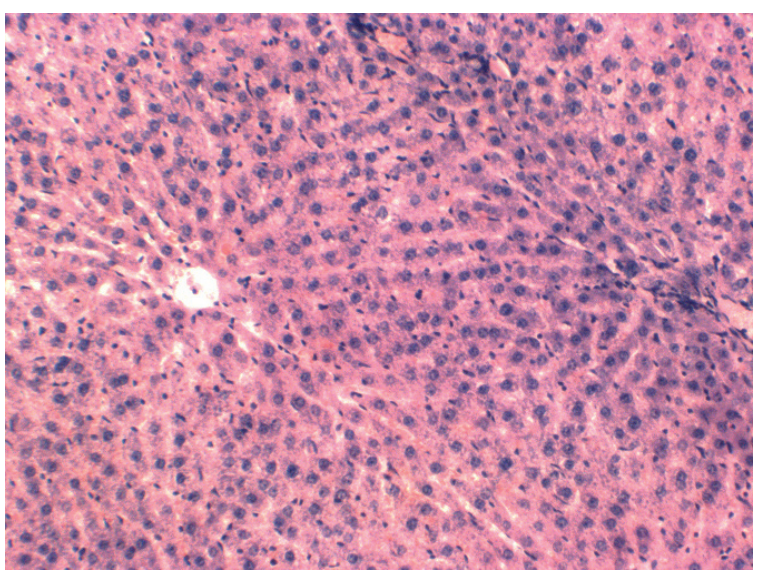

Рис. 2. Гетерогенні дистрофрічні зміни гепатоцитів 3 дрібноосередковими деструктивними проявами. Класична структура печінкової часточки загалом прослідковується. Гістологічний зріз печінки низькоемоційного щура. Забарвлення гематоксиліном і еозином. ×100.

ВЕ щурів знижується рівень АлАТ, у НЕ тварин він підвищується. Печінка більш уражена у ВЕ тварин.

3. Моделювання ЕГ у щурів з різною емоційністю спричинює ураження гепатоцитів унаслідок зростання ОМБ, що більш виражено у ВЕ тварин.

Перспективи подальших досліджень. У подальшому буде вивчено ступінь ураження серця щурів з різною емоційністю при етаноловому гепатозі.

2. Алкогольне ураження печінки: морорологічні та біохімічні особливості (експериментальне дослідження) / Ю. М. Степанов, В. І. Діденко, Н. Ю. Ошмянська [та ін.] // Гастроентерологія. - 2015. - № 3 (57). C. 66-72. 
3. Войтенко В. Оцінка розвитку експериментальної хронічної алкогольної інтоксикації / В. Войтенко, В. Конопельнюк, О. Савчук // Біологія. -2013. - № 63. C. $17-20$.

4. Кулагин Д. А. Исследование эмоциональности у крыс линии Вистар и Крушинского-Молодкиной методом "открытого поля" / Д. А. Кулагин, В.Н.Федоров // Генетика поведения. - Ленинград : Наука, 1969. - C. 35-42.

5. Лукьянова Л. В. Изучение поведенческих реакций при введении кофеина, карбамазепина и их композиций в условиях срормалинового отека у крыс / Л. В. Лукьянова // Укр. біофармац. журн. - 2016. - 42, № 1. - C. 22-26.

6. Саліга Ю. Т. Поведінка щурів, інтоксикованих хлорпірикосом, у тесті "відкрите поле" / Ю. Т. Саліга // Таврический мед.-биол. вестн. - 2012. -15, № 4 (60). C. $332-335$

\section{REFERENCES}

1. Kononenko, A.H. (2014). Vyvchennia hepatozahysnoi dii vodnoho ekstraktu lystkiv kukurudzy na modeli subhronichnoho alkoholnoho urazhennia pechinky [Study of hepatoprotective action of aqueous extract of corn leaves on the model of subchronic alcoholic liver damage]. Ukrainian Biopharmaceutical Journal, 35 (6), 43-45 [in Ukrainian].

2. Stepanov, Yu.M., Didenko, V.I., Oshmianska, N.Yu., Klenina, I.A., Petrova, K.V., Halynskyi, O.O., \& Rydenko, A.I. (2015). Alkoholne urazhennia pechinky: morfolohichni ta biokhimichni osoblyvosti (experymentalne doslidzhennia) [Alcoholic liver damage: morphological and biochemical features (experimental study)]. Hastroenterolohiia - Gastroenterology, 57 (3), 66-72 [in Ukrainian].

3. Voienko, V., Konopelniuk, V., \& Savchuk, O. (2013). Otsinka rozvytku experymentalnoi khronichnoi alkoholnoi intoksykatsii [Evaluation of the development of experimental chronic alcohol intoxication]. Biolohiia Biology, 63, 17-20 [in Ukrainian].

4. Kulagin, D.A., \& Fedorov, N. (1969). Issledovaniye emotsionalnosti u krys linii Vistar i Krushinskiy-Molodkin metodom "otkrytogo polya" [Investigation of emotionality in Wistar rats and Krushinsky-Molodkina by the "open field" method]. Genetika povedeniya - Genetics of Behavior. Leningrad: Nauka [in Russian].

5. Lukyanova, L.V. (2016). Izucheniye povedencheskikh reaktsiy pri vvedenii kofeina, karbmazepina $\mathrm{i}$ ikh kompozitsiy v usloviyakh forfalinovogo otyoka u krys [Study of behavioral reactions in the administration of caffeine, carbamazepine and their compositions in the conditions of formalin edema in rats]. Ukrainskyi biofarmatsevtychnyi jurnal - Ukrainian Biopharmaceutical Journal, 42 (1), 22-26. [in Russian].

6. Saliha, Yu.T. (2012). Povedinka shchuriv, intoksykovanykh khlorpirykosom, u testi "vidkryte pole" [The
7. Динаміка вмісту молекул середньої маси у плазмі крові щурів за тривалої алкогольної інтоксикації / К. Дудок, О. Мороз, І. Влох [та ін.] // Вісн. Львів. ун-ту. Серія біологічна. - 2005. - Вип. 39. - С. 26-32.

8. Рикало Н. А. Патоморфологічні зміни печінки та біохімічні зміни сироватки крові при гострому алкогольному гепатиті в умовах експерименту / Н. А. Рикало, І. В. Романенко // Експерим. і клініч. медицина. 2016. - 71, № 2. - С. 156-160.

9. Хышиктуев Б. С. Методы определения продуктов перекисного окисления липидов в конденсате выдыхаемого воздуха и их клиническое значение / Б. С. Хышиктуев, Н. А. Хышиктуева, В. Н. Иванов // Клинич. лаб. диагностика. - 1996. - № 3. - С. 13-15.

10. Чевари С. Роль супероксиддисмутазы в окислительных процессах клетки и метод определения ее в биологических материалах / С. Чевари, И. Чаба, й. Секей // Лаб. дело. - 1985. - № 11. - С. 678-681. behavior of rats, inhaled with chlorpyricosis, in the "open field" test]. Tavricheskiy med. boil. Vestnik - Taurian Medical and Biological Herald, 15, 60 (4), 332-335 [in Ukrainian].

7. Dudok, K., Moroz, O., Vlokh, I., Osoba, M., \& Hrynchyshyn, N. (2005). Dynamika vmistu molekul serednoi masy u plazmi krovi shchuriv za tryvaloi alkoholnoi intoksykatsii [Dynamics of the content of medium weight molecules in blood plasma of rats with prolonged alcohol intoxication]. Visnyk Lvivskoho Universytety. Seriia biolohichna - Herald of Lviv University. Biological Series, 39, 26-32 [in Ukrainian].

8. Rikalo, N.A., \& Romanenko, I.V. (2016). Patomorfolohichni zminy pechinky ta biohimichni zminy syrovatky krovi pry hostromu alcoholnomu hepatyti v umovakh experymentu [Pathomorphological changes of the liver and biochemical changes of serum in acute alcoholic hepatitis under experimental conditions]. Ekspyrymentalna i klinichna medytsyna - Experimental and Clinical Medicine, 71 (2), 156-160 [in Ukrainian].

9. Khyshiktuyev, B.S., Khyshiktuyeva, N.A., \& Ivanov, V.N. (1996). Metody opredeleniya produktov perekisnogo okisleniya lipidov $v$ kondensate vydykhayemogo vozdukha i ikh klinicheskoye znachenie [Methods of determination of products of lipids peroxidation in exhaled air condensate and their clinical significance]. Klinicheskaya laboratornaya diagnostika - Clinical Laboratory Diagnostics, 3, 13-15 [in Russian].

10. Chevary, S., Chaba, I., \& Sokey, Y. (1985). Rol superoxidismutasy $v$ okislitelnykh protsesakh kletki i metod opridileniya ego $v$ biologicheskikh materialakh [The role of superoxide dismutase in the oxidative processes of the cell and the method of its determination in biological materials]. Laboratornoye delo - Laboratory Work, 11, 678-681 [in Russian]. 


\section{ИЗМЕНЕНИЯ БИОХИМИЧЕСКИХ ПОКАЗАТЕЛЕЙ В КРОВИ ВЫСОКО- И НИЗКОЭМОЦИОНАЛЬНЫХ КРЫС ПРИ ЭТАНОЛОВОМ ГЕПАТОЗЕ}

\section{Резюме}

Вступление. Определение механизмов повреждающего воздействия этанола на печень у животных с разной реактивностью может способствовать разработке новых методов лечения и профрилактики алкогольного поражения органов и систем.

Цель исследования - выявить механизмы повреждающего воздействия при этаноловом гепатозе на организм высоко- (ВЭ) и низькоэмоциональных (НЭ) крыс-самцов.

Методы исследования. Опыты выполнены на 72 ВЭ и НЭ беспородных крысах-самцах в возрасте 5,5-6 месяцев. Животные были разделены на 3 группы: контроль 1 (К1), контроль 2 (К2) и этаноловый гепатоз (ЭГ). Эмоциональное состояние крыс определяли по методике "открытое поле". Крысы группы К2 в течение 67 дней вместо воды получали 5 \% раствор глюкозы, животные группы ЭГ - 10 \% раствор этилового спирта, разбавленного 5 \% раствором глюкозы. В сыворотке крови определяли уровень аланин- и аспартатаминотрансферазы, щелочной фоосфатазы, общего белка, глюкозы, показателей окислительной модификации белков, диеновых и триеновых конъюгатов, иифроовых оснований, активность супероксиддисмутазы, каталазы, содержание церулоплазмина и пероксидазную активность крови. Забирали печень для морфологического исследования.

Результаты и обсуждение. У НЭ крыс группы К1 отмечено большие активность процессов перекисного окисления липидов, концентрацию глюкозы, меньшие уровень аланинаминотрансферазы, содержание белка. При ЭГ продукты перекисного окисления липидов уменьшились одновременно с повышением активности антиоксидантов, но возрасло содержание продуктов окислительной модификации белков, снизилось содержание общего белка, больще у ВЭ животных; увеличилась глюкоза. У ВЭ крыс снизился уровень аланинаминотрансферазы, у НЭ животных он повысился. Печень была больше поражена у ВЭ животных.

Вывод. Моделирование этанолового гепатоза у крыс с разной эмоциональностью вызывает поражение гепатоцитов вследствие возрастания окислительной модификации белков, что больше выражено у ВЭ животных.

КЛЮЧЕВЫЕ СЛОВА: этаноловый гепатоз; высоко- и низькоэмоциональные крысы-самцы; кровь; печень.

\section{CHANGES OF BIOCHEMICAL INDICES IN THE BLOOD OF HIGH- AND LOW-EMOTIONAL RATS WITH ETHANOL HEPATOSIS}

\section{Summary}

Introduction. Determination of the mechanisms of the damaging effect of ethanol on the liver in animals with different reactivity can contribute to the development of new methods of treatment and prevention of alcohol damage of organs and systems.

The aim of the study - to determine the mechanisms of the damaging effect in ethanol hepatosis on the organism of high and low-emotional male rats (HE, LE).

Research Methods. The experiments were performed on $72 \mathrm{HE}$ and LE nonlinear male rats aged 5.5-6 months. The animals were divided into three groups - control 1 (C1), control 2 (C2) and ethanol hepatosis (EH). Emotional state of rats was determined by the "open field" method. Rats of group K2 67 days instead of water received $5 \%$ glucose solution, EH - $10 \%$ solution of ethyl alcohol diluted with $5 \%$ glucose solution. Serum levels of alanine aminotransferase (ALT), aspartate aminotransferase (AST), alkaline phosphatase, total protein, glucose, oxidative 
modification of proteins (OMP), diene and triene conjugates, schiff bases, activity of superoxide dismutase, catalase, ceruloplasmin content and peroxidase activity of blood were determined. The liver was taken for morphological examination.

Results and Discussion. In the C1 group, the LE rats had a high activity of lipid peroxidation, glucose concentration, less ALT, protein content. In EG, lipid peroxidation products decreased with increasing activity of antioxidants, but OMP products increased, more in HE; increase glucose, the protein content was decreased. In HE rats, ALT decreased, and it increased in LE animals. The defeat of the liver was greater in the ET of animals.

Conclusion. Modeling of ethanol hepatosis in rats with different emotionality causes the hepatocytes to break down as a result of an increase in the oxidative modification of proteins, which is more pronounced in the HE animals.

KEY WORDS: ethanol hepatoses; high and low-emotional male rats; blood; liver.

Отримано 20.07.18

Адреса для листування: О. В. Денесріль, Тернопільський державний медичний університет імені І. Я. Горбачевського, майдан Волі, 1, Тернопіль, 46001, Україна, e-mail: denefil@tdmu.edu.ua. 